\title{
Rearing Velocity Impacts on Landlocked Fall Chinook Salmon (Oncorhynchus tshawytscha) Growth, Condition, and Survival
}

\author{
Timothy M. Parker, Michael E. Barnes \\ South Dakota Department of Game, Fish and Parks, Spearfish, McNenny State Fish Hatchery, South Dakota, \\ USA \\ Email: Timothy.Parker@state.sd.us
}

Received 12 July 2014; revised 27 August 2014; accepted 13 September 2014

Copyright (C) 2014 by authors and Scientific Research Publishing Inc.

This work is licensed under the Creative Commons Attribution International License (CC BY). http://creativecommons.org/licenses/by/4.0/

(c) (i) Open Access

\begin{abstract}
Juvenile landlocked Chinook salmon (Oncorhynchus tshawytscha) (mean \pm SD initial weight $2.6 \pm$ $0.7 \mathrm{~g}$, fork length $6.3 \pm 0.5$ ) were reared in three different water velocities $[0.5,1.5$ and 3.0 body length/s (BL/s)] for four weeks to determine possible effects of water velocity on growth, condition, and survival. Fish were sampled for weight, fork length, condition factor, hepatosomatic index (HSI), viscerosomatic index (VSI), and fin erosion after four weeks of feeding to satiation. At the end of the feeding trial, the fish were handled and transported to simulate stocking, with survival observed over the following $10 \mathrm{~d}$. Following four weeks of feeding, fish reared in 0.5 and 1.5 $\mathrm{BL} / \mathrm{s}$ had the same growth and food conversion ratio, but fish reared at $3.0 \mathrm{BL} / \mathrm{s}$ had a significant reduction in both metrics. Furthermore, fish reared at $1.5 \mathrm{BL} / \mathrm{s}$ had a significantly higher condition factor than fish reared in other treatments. No significant differences were found for HSI, VSI, fin erosion, or survival. The results from this study indicate that a moderate velocity $(1.5 \mathrm{BL} / \mathrm{s})$, which is necessary for circular tanks to be self-cleaning, is not detrimental to fish growth or condition, but a faster water velocity $(3.0 \mathrm{BL} / \mathrm{s})$ negatively affects fish growth and food utilization.
\end{abstract}

\section{Keywords}

Chinook Salmon, Oncorhynchus tshawytscha, Velocity, Circular Tanks

\section{Introduction}

Using rearing velocities to exercise cultured fish has been shown to influence fish growth [1]-[3] and food conversion [4] [5]. Rainbow trout (Oncorhynchus mykiss) forced to swim at 1 body length/s (BL/s) grew twice as 
much and had more efficient protein conversion than unexercised fish over a six week period [1]. However, the effect of exercise on Chinook salmon (Oncorhynchus tshawytscha) led to reduced growth. Kiessling et al. [6] showed that Chinook salmon swimming at speeds of $0.5-1.5 \mathrm{BL} / \mathrm{s}$ for 212 days had the same growth rate, but higher swimming speeds resulted in increased feed consumption and decreased food conversion ratios (FCR). However, decreased growth performance of Chinook salmon reared at higher water velocities may be compensated by increased fish quality [4] [7] and increased post-stocking survival [8].

Exercised fish have been shown to have increased swimming performance [2] [7] [8] [10] and reduced stress [11]. Swimming comes with energetic costs which may result in decrease FCR, but exercised fish are better suited for environments with moving water. The swimming performance of brook trout (Salvelinus fontinalis) has been shown to be significantly improved in exercised fish, consequently allowing them to swim farther in rapidly moving water [2]. Gallaugher et al. [10] showed that exercised Chinook salmon are able to increase their maximum oxygen consumption, enabling them to provide oxygen for the physiological processes associated with swimming. Therefore, exercise reduces the metabolic cost of swimming and allows for the maintenance of physiological functions, resulting in post-stocking benefits.

Cresswell and Williams [8] found that brown trout (Salmotrutta) reared in indoor tanks and acclimated to flowing water (i.e. exercise) had a higher percentage of recapture after stocking into flowing waters. In addition, exercised fish may be more aesthetically pleasing to angler post-stocking due to reduced fin erosion. Exercised Arctic char (Salvelinus alpinus) had significantly reduced fin damage compared to fish reared in standing water [4].

No previous studies have been conducted examining the effects of exercise on growth of landlocked Chinook salmon in general or landlocked fall Chinook salmon from Lake Oahe, South Dakota. This strain of fish is relatively unique and has been genetically isolated from all other strains of Chinook salmon since 1989 [12] [13]. Because this salmon population is maintained solely by stocking, and progeny may be limited during certain years [13], using exercise to improve hatchery rearing performance and post-stocking survival is important. Additionally, it is unknown how tank velocities required for tanks to be self-cleaning influence production. Thus, the objective of this study was to investigate the effects of rearing velocity on Lake Oahe fall Chinook salmon growth, condition, and survival.

\section{Materials and Methods}

Fish were reared at McNenny State Fish Hatchery, Spearfish, South Dakota, using progeny of landlocked fall Chinook salmon from Lake Oahe obtained for spawning on October 22, 2013. The fish began feeding on December 23, 2013 and were reared using standard hatchery practices until the beginning of the experiment. On February, 26, 2014 fish (mean \pm SD initial weight $2.6 \pm 0.7 \mathrm{~g}$, fork length $6.3 \pm 0.5 \mathrm{~cm}, \mathrm{n}=70$ ) were combined into two tanks $(196.25 \mathrm{~kg})$ and then randomly distributed to nine, $2000-\mathrm{L}$ circular tanks (1.8 $\mathrm{m}$ in diameter and $0.8 \mathrm{~m}$ deep) at equal densities of approximately 8076 fish $(48.1 \pm 0.3 \mathrm{~kg} / \mathrm{tank})$.

Three velocity treatments $(0.5,1.5$, and $3.0 \mathrm{BL} / \mathrm{s})$ were assigned to the nine tanks $(\mathrm{n}=3)$. A velocity of 0.5 $\mathrm{BL} / \mathrm{s}$ was not enough to force fish to swim continuously into the current and fish were able to haphazardly swim in their tanks. This treatment was used as a proxy for a non-swimming group because it allowed for the fish to not have to continuously swim and provided some rotation in the water to assist with maintaining clean tanks. Water velocity was adjusted by manipulating the angle of the spray bar and determined by recording the time it took for a neutral buoyant object to orbit the tank. Ten fish from each tank were measured for weight and fork length every seven days. Water velocity was re-checked every seven days as well.

Well water at a constant temperature of $11^{\circ} \mathrm{C}$ (total hardness as $\mathrm{CaCO}_{3}, 360 \mathrm{mg} / \mathrm{L}$; alkalinity as $\mathrm{CaCO}_{3}, 210$ $\mathrm{mg} / \mathrm{L}$; pH, 7.6; total dissolved solids, $390 \mathrm{mg} / \mathrm{L}$ ) was supplied to the tanks at approximately $47.8 \mathrm{~L} / \mathrm{min}$. Fish were fed every 15 minutes during daylight hours using automatic feeders with $1.0 \mathrm{~mm}$ extruded sinking 45-19 salmon diet (Skretting; Tooele, Utah). Feeding rates were determined by the hatchery constant method [14], with a planned feed conversion of 1.1 and a maximum growth rate of $0.08 \mathrm{~cm} /$ day, a rate which is at or above satiation for this strain at McNenny Hatchery. Dead fish were removed daily and weighed. At the end of four weeks of feeding, biomass for each tank was determined by weighing the entire tank. Along with tank biomass, data was also collected from 20 individual fish per tank, including fork length to the nearest $1.0 \mathrm{~mm}$, weight to the nearest $0.001 \mathrm{~g}$, pectoral fin length to the nearest $0.1 \mathrm{~mm}$, liver weight to the nearest $0.001 \mathrm{~g}$, and viscera weight to the nearest $0.0001 \mathrm{~g}$. The following equations were used: 


$$
\text { Condition Factor }(\mathrm{K})=\left[\text { weight }(\mathrm{g}) / \text { fork length }(\mathrm{cm})^{3}\right] \times 100
$$

Fin erosion $=[($ fork length of pectoral fin $\div$ fork length $) \times 100][15]$

Viscerosomatic index $($ VSI $)=[($ weight of viscera $\div$ total fish weight $) \times 100]$

Hepatosomatic index $($ HSI $)=[($ liver weight $\div$ total fish weight $) \times 100]$

Food conversion ratio(FCR) = feed consumed/weight gain

As part of weighing the entire tank for biomass determination at the end of four weeks, the fish, which were part of hatchery production, were loaded into a transfer tank using dipnets containing approximately $10 \mathrm{~kg}$ per net load. The fish were then transported to another part of the hatchery complex for continued rearing in larger units prior to stocking. The entire procedure (netting and transportation) took approximately 20 min per tank. To ascertain any possible effects of exercise on post-handling mortality and stress, 100 fish from each tank were returned to their original experimental tanks. Mortality and fin erosion were monitored for these fish for the next $10 \mathrm{~d}$.

Data was analyzed using the SPSS (9.0) statistical analysis program (SPSS, Chicago, Illinois, USA). Growth, FCR, VSI, HSI, fin erosion, and condition factor were analyzed using One-Way ANOVA with a Tukey post-hoc test. Weekly changes in fork length were analyzed using a One-Way ANOVA for each week. Data was consider significantly different when $\mathrm{P}<0.05$.

\section{Results}

Following 28 days of feeding, the fastest swimming treatment (3.0 BL/s) had a significantly lower weight gain than the other two treatments, but the weight gain of fish reared at the other two velocities was not significantly different (Figure 1). FCR results followed a similar pattern (Figure 2). Changes in fork length each week during the duration of the experiment were not significantly different (Table 1). However, P values decreased over time

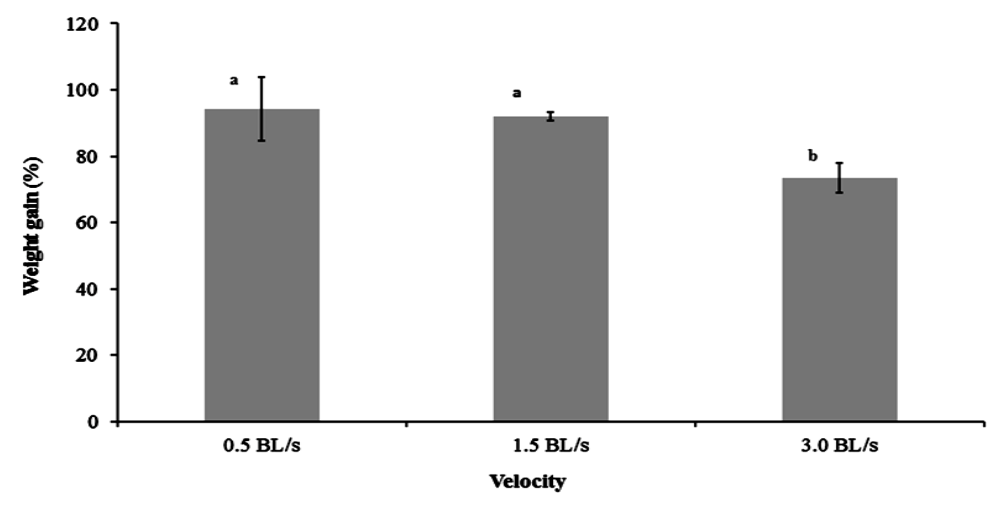

Figure 1. Mean $( \pm \mathrm{SD})$ weight gain (\%) of landlocked fall Chinook salmon reared at three different water velocities (body length/s $=\mathrm{BL} / \mathrm{s}$ ) for four weeks. Means with different letters are significantly different $(\mathrm{P}<0.05, \mathrm{n}=3)$.

Table 1. Mean $( \pm \mathrm{SD})$ fork length $(\mathrm{cm})$ of landlocked fall Chinook salmon reared in three different water velocities. Ten individuals were measured per tank (body length/s = BL/s; $n=3$ ).

\begin{tabular}{ccccc}
\hline & & & & \\
\hline Week & 0.5 & 1.5 & 3.0 & P \\
\hline 1 & $6.6 \pm 0.2$ & $6.4 \pm 0.1$ & $6.4 \pm 0.2$ & 0.197 \\
2 & $7.0 \pm 0.2$ & $6.9 \pm 0.1$ & $6.7 \pm 0.1$ & 0.103 \\
3 & $7.2 \pm 0.3$ & $7.3 \pm 0.2$ & $7.1 \pm 0.1$ & 0.559 \\
4 & $7.7 \pm 0.1$ & $7.8 \pm 0.1$ & $7.4 \pm 0.2$ & 0.058 \\
\hline
\end{tabular}


and approached significance by Week 4 .

Survival was unaffected by swimming velocity during the four week feeding trial, and for ten days after moving (Table 2). The moderate swimming speed treatment (1.5 BL/s) led to a significant increase in condition factor compared to the slow $(0.5 \mathrm{BL} / \mathrm{s})$ and fast $(3.0 \mathrm{BL} / \mathrm{s})$ swimming speeds (Figure 3$)$. However, there were no significant differences in HSI or VSI (Figure 4 and Figure 5). There were also no significant differences in fin erosion among the velocity treatments at the end of the feeding trial or post-handling (Figure 6 and Figure 7).

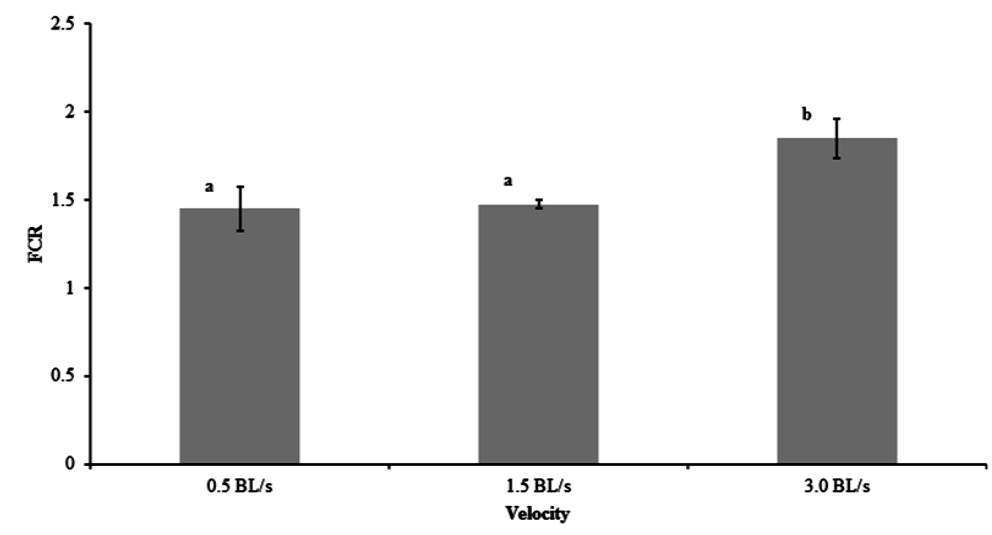

Figure 2. Mean $( \pm \mathrm{SD}$ ) food conversion ratio (FCR) of landlocked fall Chinook salmon reared at three different water velocities (body length $/ \mathrm{s}=\mathrm{BL} / \mathrm{s}$ ) for four weeks. Means with different letters are significantly different $(\mathrm{P}<$ $0.05, n=3)$.

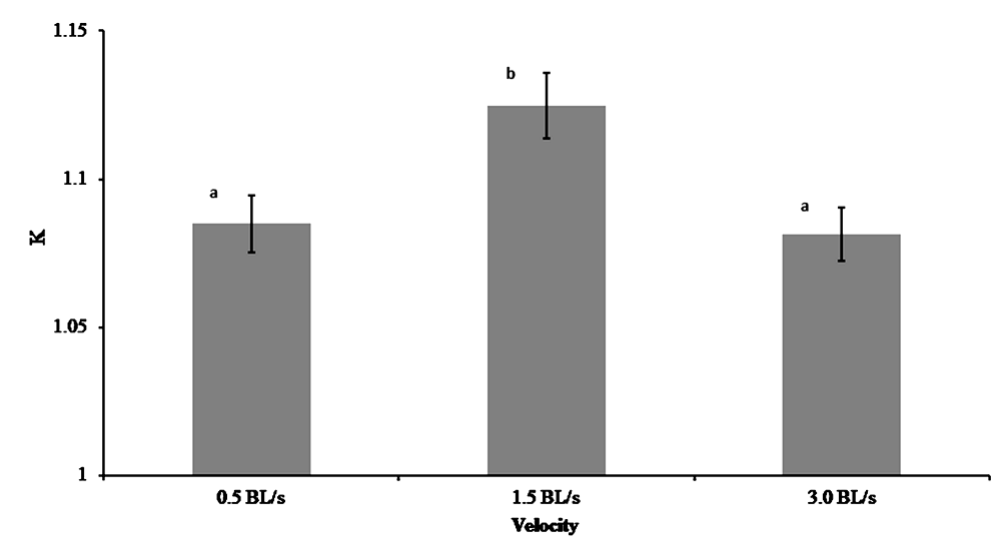

Figure 3. Mean ( \pm SD) condition factor $(K)$ of landlocked fall Chinook salmon reared at three different water velocities (body length/s $=\mathrm{BL} / \mathrm{s}$ ) for four weeks. Means with different letters are significantly different $(P<0.05, n=3)$.

Table 2. Mean $( \pm \mathrm{SD})$ percent survival of landlocked fall Chinook salmon reared in three different water velocities during a four week feeding trial and ten days post-handling $(\mathrm{n}=3)$.

\begin{tabular}{ccc}
\hline Trial & Velocity $(\mathrm{BL} / \mathrm{s})^{\mathrm{a}}$ & \% Survival \\
\hline Feeding & 0.5 & $99.91 \pm 0.03$ \\
& 1.5 & $99.88 \pm 0.04$ \\
Post-handling & 3 & $99.82 \pm 0.01$ \\
& 0.5 & $100.00 \pm 0.00$ \\
& 1.5 & $100.00 \pm 0.00$ \\
\hline
\end{tabular}




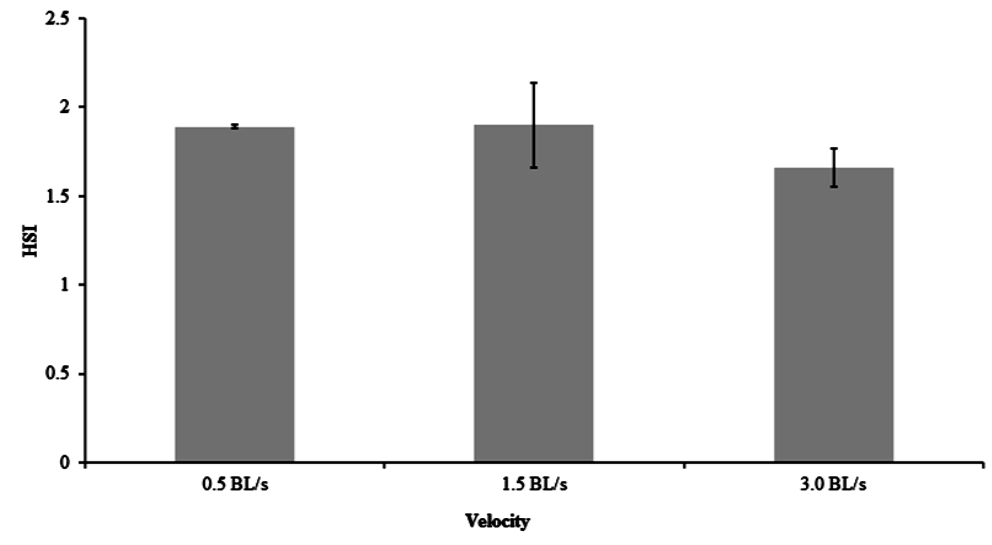

Figure 4. Mean ( \pm SD) hepatosomatic index (HSI) of landlocked fall Chinook salmon reared at three different water velocities (body length $/ \mathrm{s}=\mathrm{BL} / \mathrm{s}$ ) for four weeks $(n=3)$. No significant differences were found between the treatments.

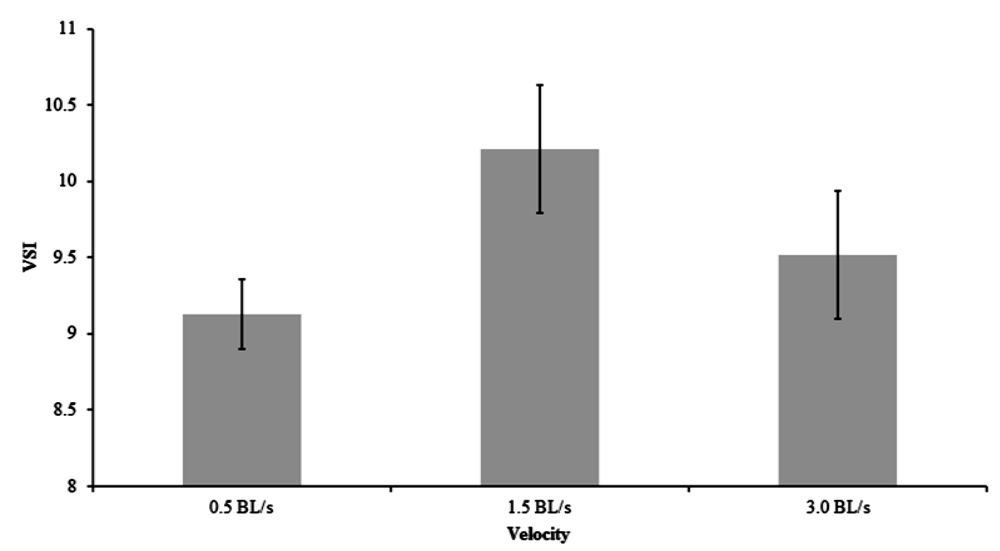

Figure 5. Mean ( \pm SD) visceral-somatic index (VSI) of landlocked fall Chinook salmon reared at three different water velocities (body length $/ \mathrm{s}=\mathrm{BL} / \mathrm{s}$ ) for four weeks $(n=3)$. No significant differences were found between the treatments.

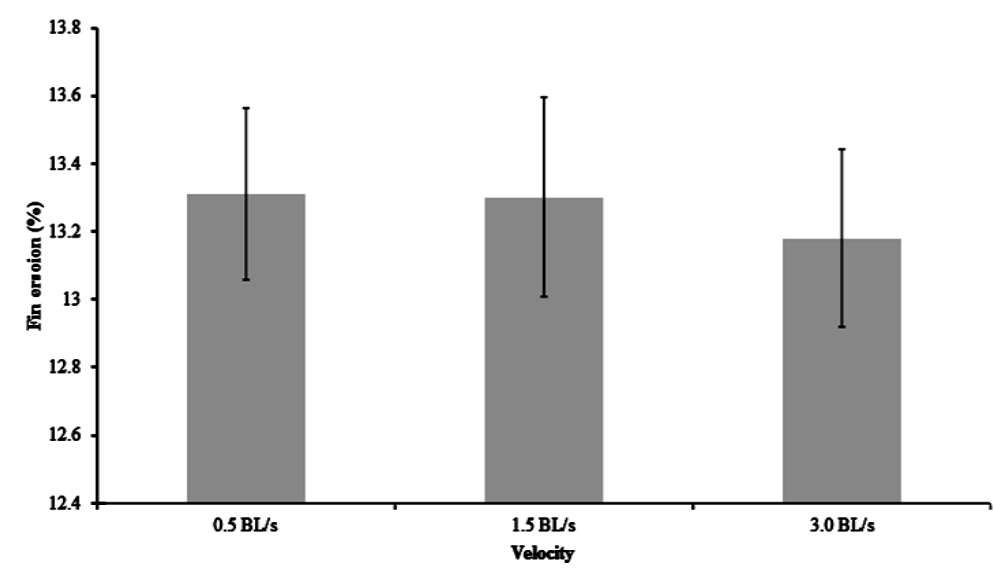

Figure 6. Mean ( $\pm \mathrm{SD}$ ) pectoral fin erosion of landlocked fall Chinook salmon reared at three different water velocities (body length/s $=\mathrm{BL} / \mathrm{s}$ ) for four weeks $(n=3)$. No significant differences were found between the treatments. 


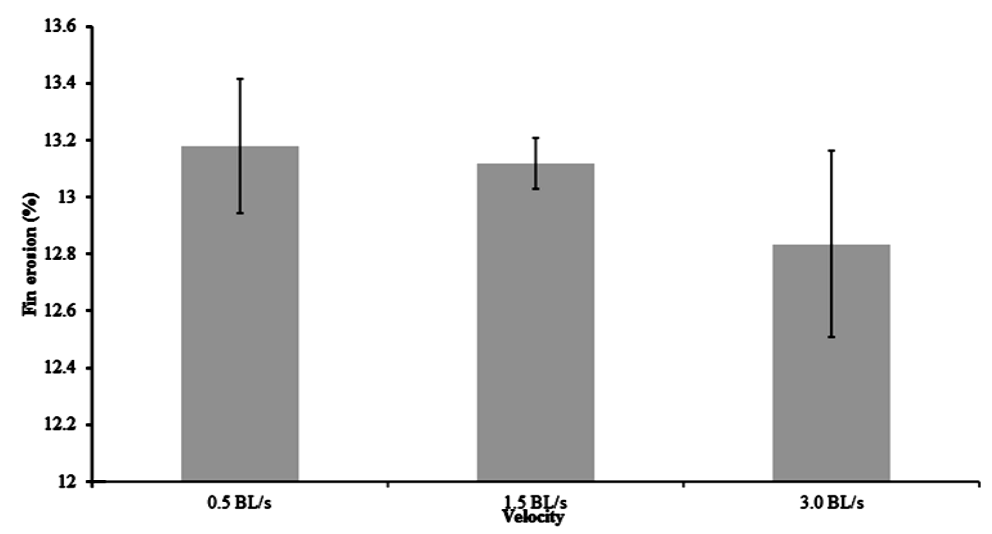

Figure 7. Mean ( \pm SD) pectoral fin erosion ten days after handling stress of landlocked fall Chinook salmon reared at three different water velocities (body length/s = BL/s) for four weeks $(n=3)$. No significant differences were found between the treatments.

\section{Discussion}

The negative impacts on growth and FCR associated with the $3.0 \mathrm{BL} / \mathrm{s}$ swimming speed likely indicates an increased energetic cost compared to the two lesser velocities. However, $1.5 \mathrm{BL} / \mathrm{s}$ which is required for tanks to sufficiently be self-cleaning did not result in any reduction in growth or FCR in comparison to fish in the 0.5 $\mathrm{BL} / \mathrm{s}$. The water velocity in the $0.5 \mathrm{BL} / \mathrm{s}$ treatments was slow enough that fish were not forced to continuously swim and were able to randomly swim in their tank. Chinook salmon have been shown to have an exponential increase in oxygen consumption as swimming speeds increase [10]. Kiessling et al. [5] also found that Chinook salmon exercised at speeds of 0.5 and $1.5 \mathrm{BL} / \mathrm{s}$ had no difference in growth, but the fish swimming at $1.5 \mathrm{BL} / \mathrm{s}$ had a less efficient FCR. The lack of difference in growth in the fish swimming at 0.5 and $1.5 \mathrm{BL} / \mathrm{s}$ may be due to improved physiological functions in fish swimming at $1.5 \mathrm{BL} / \mathrm{s}$ offsetting the increase in energetic cost associated with swimming. Rainbow trout were shown to have a $10 \%$ decrease in oxygen consumption when swimming at a constant speed and switching from active to ram ventilation [16]. Furthermore, Gallaugher et al. [10] showed the exercised Chinook salmon had improved osmoregulation, enabling them to multitask physiological functions while swimming, such as prioritizing the metabolic processes associated with digestion [9]. Unlike Kiessling et al. [6] who noted a decrease in food utilization efficiency when Chinook salmon were swimming at 1.5 BL/s compared to $0.5 \mathrm{BL} / \mathrm{s}$, we found no difference in FCR between fish swimming at the same speeds. However, Kiessling et al. [6] used much larger fish (75 g) in a much longer experiment (212 d). The Our FCR data is similar to previous studies using Lake Oahe Chinook salmon reared at high density [17]. Thus, even though swimming has energetic cost, the increased energy utilized is offset by improvements to physiological functions. It should be noted that our FCR values may not be directly comparable with those of other studies, because FCR can be influenced by feeding rates, feeding strategies, fish size, rearing density, and water temperatures [18]-[23]. Additionally, these results may only apply for Lake Oahe Chinook salmon at this size and age as it is unknown how size and age influences the effects of exercise on these fish.

Survival in our study was unaffected by treatment and hatchery handling. However, Cresswell and Williams [8] showed that brown trout acclimated to flowing water had a higher percentage of recapture post-stocking in flowing waters. Furthermore, Woodward and Smith [11] noted that exercised rainbow trout had significantly lower plasma cortisol levels when allowed to rest, which may indicate that exercised trout are better adapted to handle stress, even in water with no flow. Our handling procedures likely did not adequately mimic the stressors associated with actual stocking, making it difficult to predict whether our treatment conditions could enhance post-stocking. Barton et al. [24] found that brief handling led to elevated plasma cortisol levels for only $2 \mathrm{~h}$, while stocking caused cortisol levels to remain elevated for 4 to $8 \mathrm{~d}$. Therefore, in future studies it is critical for handling procedures to induce a large amount of stress to clearly understand the effects of exercise on poststocking survival.

The lack of significant differences in the weekly lengths among the treatment groups is likely due to the short length of this study. The decrease in $\mathrm{P}$ values as the study progressed suggests that fish sizes may have become 
significantly different in future weeks had the experiment continued. Christiansen et al. [25] did not detect a significant increase in the weights of resting and exercising Arctic charr until 42 days. Unfortunately, our study had to conclude after four weeks (28 days) because the fish needed to be transferred to larger tanks as part of hatchery production. Although not significantly different, trends in the data appear to indicate that the fish swimming at $1.5 \mathrm{BL} / \mathrm{s}$ were smallest after one week of swimming and were the largest by the end of the experiment. If this is an accurate trend, it may indicate that these fish initially had a period of acclimation, which would be consistent with the results of Woodward and Smith [11].

Bosakowski and Wagner [26] found that density and environmental conditions were significantly related to fin erosion. Furthermore, Arctic charr fed in excess and allowed to haphazardly swim in their tanks had increased aggressive behavior and damaged fins [4]. It was expected that fish in the $0.5 \mathrm{BL} / \mathrm{s}$ would exhibit increased aggressive behavior resulting in increased fin erosion, but this did not occur. The lack of significant differences in fin erosion among the treatments likely indicates a relative lack of environmental stress and a lack of aggressive behavior.

The increase in condition factor of fish swimming at $1.5 \mathrm{BL} / \mathrm{s}$ possibly indicates that the fish did have increased energy status via whole body total lipids [27]. Furthermore, similar results to ours were found by Jørgensen and Jobling [28] in which Atlantic salmon (Salmosalar) swimming at 1.5 and $2.0 \mathrm{BL} / \mathrm{s} \mathrm{had} \mathrm{a} \mathrm{signifi-}$ cant increase in condition factor compared to resting fish. However, Jørgensen and Jobling [28] did not have a treatment group comparable to fish swimming at $3.0 \mathrm{BL} / \mathrm{s}$. We were surprised that fish swimming at $3.0 \mathrm{BL} / \mathrm{s}$ did not result in a significantly reduced HSI as a result of the increased energy demand caused by the high velocity, anticipating that the strenuous exercise would lead to decreased glycogen stores and subsequent reductions in liver weight. However, Chellappa et al. [29] found that HSI was poor at indicating the energy status of three-spined stickleback (Gasterosteus aculeatus), noting that during periods of low food availability, water content increased in the liver as glycogen reserves were mobilized. Therefore, fish swimming at $3.0 \mathrm{BL} / \mathrm{s}$ may have had reduced glycogen reserves which were not accurately reflected by the HSI values. We also anticipated that VSI would decrease in the fish forced to swim at $3.0 \mathrm{BL} / \mathrm{s}$, due to a relative decrease in the amount of visceral fat. However, very little fat was observed in any of the treatment groups. The GI tract was nearly absent of attached visceral fat, despite being fed at or slightly above satiation. This could indicate that that energy was being allocated to growth and not stored. The fish used in this study were at a life stage in which rainbow trout have been shown to have a low amount of lipid content (2\%) [30]. However, after this stage, lipid content rapidly increases until the fish are $20 \mathrm{~g}$ with approximately 6\% lipid [30]. It is likely that if the experiment were to be conducted over a longer period of time, or until fish were of a size where more energy was allocated to energy storage, the VSI data would be more insightful to the energetics of each the treatment groups.

In conclusion, the results from our study indicate that moderate swimming speeds required for tanks to be self-cleaning $(1.5 \mathrm{BL} / \mathrm{s})$ have no negative impact on landlocked fall Chinook salmon growth or feed conversion ratio. Furthermore, $1.5 \mathrm{BL} / \mathrm{s}$ appears to have a positive impact on fish condition factor, indicating that a moderate swimming speed of $1.5 \mathrm{BL} / \mathrm{s}$ improves the energy status in landlocked fall Chinook salmon from Lake Oahe. However, further longer term studies need to be done, and such studies should include observations on post-stocking survival.

\section{Acknowledgements}

The authors thank Patrick Nero, Eric Krebs, Kristen Becket, and Dennis Bailey for their assistance with this study.

\section{References}

[1] Houlihan, D. and Laurent, P. (1987) Effects of Exercise Training on the Performance, Growth, and Protein Turnover of Rainbow Trout (Salmogairdneri). Canadian Journal of Fisheries and Aquatic Sciences, 44, 1614-1621. http://dx.doi.org/10.1139/f87-195

[2] Leon, K.A. (1986) Effect of Exercise on Feed Consumption, Growth, Food Conversion, and Stamina of Brook Trout. The Progressive Fish-Culturist, 48, 43-46. http://dx.doi.org/10.1577/1548-8640(1986)48<43:EOEOFC>2.0.CO;2

[3] Young, P.S. and Cech Jr., J.J. (1993) Improved Growth, Swimming Performance, and Muscular Development in Exercise-Conditioned Young-of-the-Year Striped Bass (Moronesaxatilis). Canadian Journal of Fisheries and Aquatic Sciences, 50, 703-707. http://dx.doi.org/10.1139/f93-080 
[4] Christiansen, J.S. and Jobling, M. (1990) The Behaviour and the Relationship between Food Intake and Growth of Juvenile Arctic Charr, Salvelinusalpinus L., Subjected to Sustained Exercise. Canadian Journal of Zoology, 68, 21852191. http://dx.doi.org/10.1139/z90-303

[5] Davison, W. and Goldspink, G. (1977) The Effect of Prolonged Exercise on the Lateral Musculature of the Brown Trout (Salmotrutta). Journal of Experimental Biology, 70, 1-12.

[6] Kiessling, A., Higgs, D., Dosanjh, B. and Eales, J. (1994) Influence of Sustained Exercise at Two Ration Levels on Growth and Thyroid Function of All-Female Chinook Salmon (Oncorhynchus tshawytscha) in Seawater. Canadian Journal of Fisheries and Aquatic Sciences, 51, 1975-1984. http://dx.doi.org/10.1139/f94-200

[7] Bagatto, B., Pelster, B. and Burggren, W. (2001) Growth and Metabolism of Larval zebrafish: Effects of Swim Training. Journal of Experimental Biology, 204, 4335-4343.

[8] Cresswell, R. and Williams, R. (1983) Post-Stocking Movements and Recapture of Hatchery—Reared Trout Released into Flowing Waters-Effect of Prior Acclimation to Flow. Journal of Fish Biology, 23, 265-276. http://dx.doi.org/10.1111/j.1095-8649.1983.tb02904.x

[9] Thorarensen, H. and Farrell, A.P. (2006) Postprandial Intestinal Blood Flow, Metabolic Rates, and Exercise in Chinook Salmon (Oncorhynchus tshawytscha). Physiological and Biochemical Zoology, 79, 688-694. http://dx.doi.org/10.1086/505512

[10] Gallaugher, P., Thorarensen, H., Kiessling, A. and Farrell, A. (2001) Effects of High Intensity Exercise Training on Cardiovascular Function, Oxygen Uptake, Internal Oxygen Transport and Osmotic Balance in Chinook Salmon (Oncorhynchus tshawytscha) during Critical Speed Swimming. The Journal of Experimental Biology, 204, 2861-2872.

[11] Woodward, J. and Smith, L. (1985) Exercise Training and the Stress Response in Rainbow Trout, Salmo gairdneri Richardson. Journal of Fish Biology, 26, 435-447. http://dx.doi.org/10.1111/j.1095-8649.1985.tb04283.x

[12] Wipf, M.M., Barnes, M.E. and Durben, D. (2014) Lack of Temporal Variation in Egg Size in Landlocked Fall Chinook Salmon from Lake Oahe, South Dakota. Transactions of the American Fisheries Society, 143, 289-293. http://dx.doi.org/10.1080/00028487.2013.847864

[13] Barnes, M.E., Hanten, R.P., Cordes, R.J., Sayler, W.A. and Carreiro, J. (2000) Reproductive Performance of Inland Fall Chinook Salmon. North American Journal of Aquaculture, 62, 203-211. http://dx.doi.org/10.1577/1548-8454(2000)062<0203:RPOIFC>2.3.CO;2

[14] Buterbaugh, G.L. and Willoughby, H. (1967) A Feeding Guide for Brook, brown, and Rainbow Trout. The Progressive Fish-Culturist, 29, 210-215. http://dx.doi.org/10.1577/1548-8640(1967)29[210:AFGFBB]2.0.CO;2

[15] Kindschi, G.A. (1987) Method for Quantifying Degree of Fin Erosion. The Progressive Fish-Culturist, 49, 314-315. http://dx.doi.org/10.1577/1548-8640(1987)49<314:MFQDOF>2.0.CO;2

[16] Steffensen, J.F. (1985) The Transition between Branchial Pumping and Ram Ventilation in Fishes: Energetic Consequences and Dependence on Water Oxygen Tension. Journal of Experimental Biology, 114, 141-150.

[17] Barnes, M.E., Wipf, M.M., Domenici, N.R., Kummer, W.M. and Hanten, R.P. (2013) Decreased Hatchery Rearing Density Improves Poststocking Harvest and Return to Spawning of Landlocked Fall Chinook Salmon. North American Journal of Aquaculture, 75, 244-250. http://dx.doi.org/10.1080/15222055.2013.768573

[18] Cole, B.A. and Boyd, C.E. (1986) Feeding Rate, Water Quality, and Channel Catfish Production in Ponds. The Progressive Fish-Culturist, 48, 25-29. http://dx.doi.org/10.1577/1548-8640(1986)48<25:FRWQAC >2.0.CO;2

[19] Holm, J.C., Refstie, T. and Bø, S. (1990) The Effect of Fish Density and Feeding Regimes on Individual Growth Rate and Mortality in Rainbow Trout (Oncorhynchus mykiss). Aquaculture, 89, 225-232. http://dx.doi.org/10.1016/0044-8486(90)90128-A

[20] Einen, O. and Roem, A. (1997) Dietary Protein/Energy Ratios for Atlantic Salmon in Relation to Fish Size: Growth, Feed Utilization and Slaughter Quality. Aquaculture Nutrition, 3, 115-126. http://dx.doi.org/10.1046/j.1365-2095.1997.00084.X

[21] Procarione, L.S., Barry, T.P. and Malison, J.A. (1999) Effects of High Rearing Densities and Loading Rates on the Growth and Stress Responses of Juvenile Rainbow Trout. North American Journal of Aquaculture, 61, 91-96. http://dx.doi.org/10.1577/1548-8454(1999)061<0091:EOHRDA>2.0.CO;2

[22] Azzaydi, M., Martinez, F., Zamora, S., Sánchez-Vázquez, F. and Madrid, J. (2000) The Influence of Nocturnal vs. Diurnal Feeding under Winter Conditions on Growth and Feed Conversion of European Sea Bass (Dicentrarchus labrax, L.). Aquaculture, 182, 329-338. http://dx.doi.org/10.1016/S0044-8486(99)00276-8

[23] Van Ham, E.H., Berntssen, M.H., Imsland, A.K., Parpoura, A.C., WendelaarBonga, S.E., et al. (2003) The Influence of Temperature and Ration on Growth, Feed Conversion, Body Composition and Nutrient Retention of Juvenile Turbot (Scophthalmus maximus). Aquaculture, 217, 547-558. http://dx.doi.org/10.1016/S0044-8486(02)00411-8

[24] Barton, B.A., Peter, R.E. and Paulencu, C.R. (1980) Plasma Cortisol Levels of Fingerling Rainbow Trout (Salmo 
gairdneri) at Rest, and Subjected to Handling, Confinement, Transport, and Stocking. Canadian Journal of Fisheries and Aquatic Sciences, 37, 805-811. http://dx.doi.org/10.1139/f80-108

[25] Christiansen, J.S., Ringø, E. and Jobling, M. (1989) Effects of Sustained Exercise on Growth and Body Composition of First-Feeding Fry of Arctic Charr, Salvelinus alpinus (L.). Aquaculture, 79, 329-335. http://dx.doi.org/10.1016/0044-8486(89)90474-2

[26] Bosakowski, T. and Wagner, E.J. (1994) A Survey of Trout Fin Erosion, Water Quality, and Rearing Conditions at State Fish Hatcheries in Utah. Journal of the World Aquaculture Society, 25, 308-316. http://dx.doi.org/10.1111/j.1749-7345.1994.tb00196.x

[27] Herbinger, C. and Friars, G. (1991) Correlation between Condition Factor and Total Lipid Content in Atlantic Salmon, Salmo salar L., parr. Aquaculture Research, 22, 527-529. http://dx.doi.org/10.1111/j.1365-2109.1991.tb00766.x

[28] Jørgensen, E.H. and Jobling, M. (1993) The Effects of Exercise on Growth, Food Utilisation and Osmoregulatory Capacity of Juvenile Atlantic Salmon, Salmo salar. Aquaculture, 116, 233-246. http://dx.doi.org/10.1016/0044-8486(93)90011-M

[29] Chellappa, S., Huntingford, F., Strang, R. and Thomson, R. (1995) Condition Factor and Hepatosomatic Index as Estimates of Energy Status in Male Three-Spined Stickleback. Journal of Fish Biology, 47, 775-787. http://dx.doi.org/10.1111/j.1095-8649.1995.tb06002.x

[30] Post, J.R. and Parkinson, E. (2001) Energy Allocation Strategy in Young Fish: Allometry and Survival. Ecology, 82, 1040-1051. http://dx.doi.org/10.1890/0012-9658(2001)082[1040:EASIYF]2.0.CO;2 
Scientific Research Publishing (SCIRP) is one of the largest Open Access journal publishers. It is currently publishing more than 200 open access, online, peer-reviewed journals covering a wide range of academic disciplines. SCIRP serves the worldwide academic communities and contributes to the progress and application of science with its publication.

Other selected journals from SCIRP are listed as below. Submit your manuscript to us via either submit@scirp.org or Online Submission Portal.
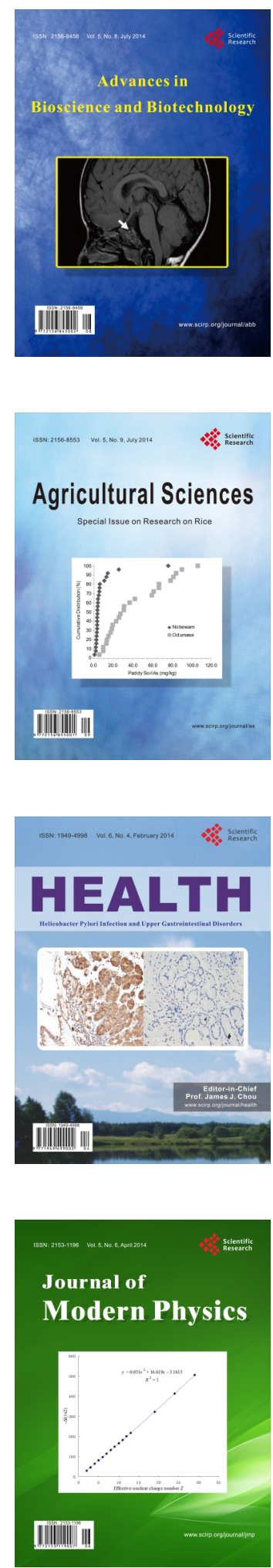
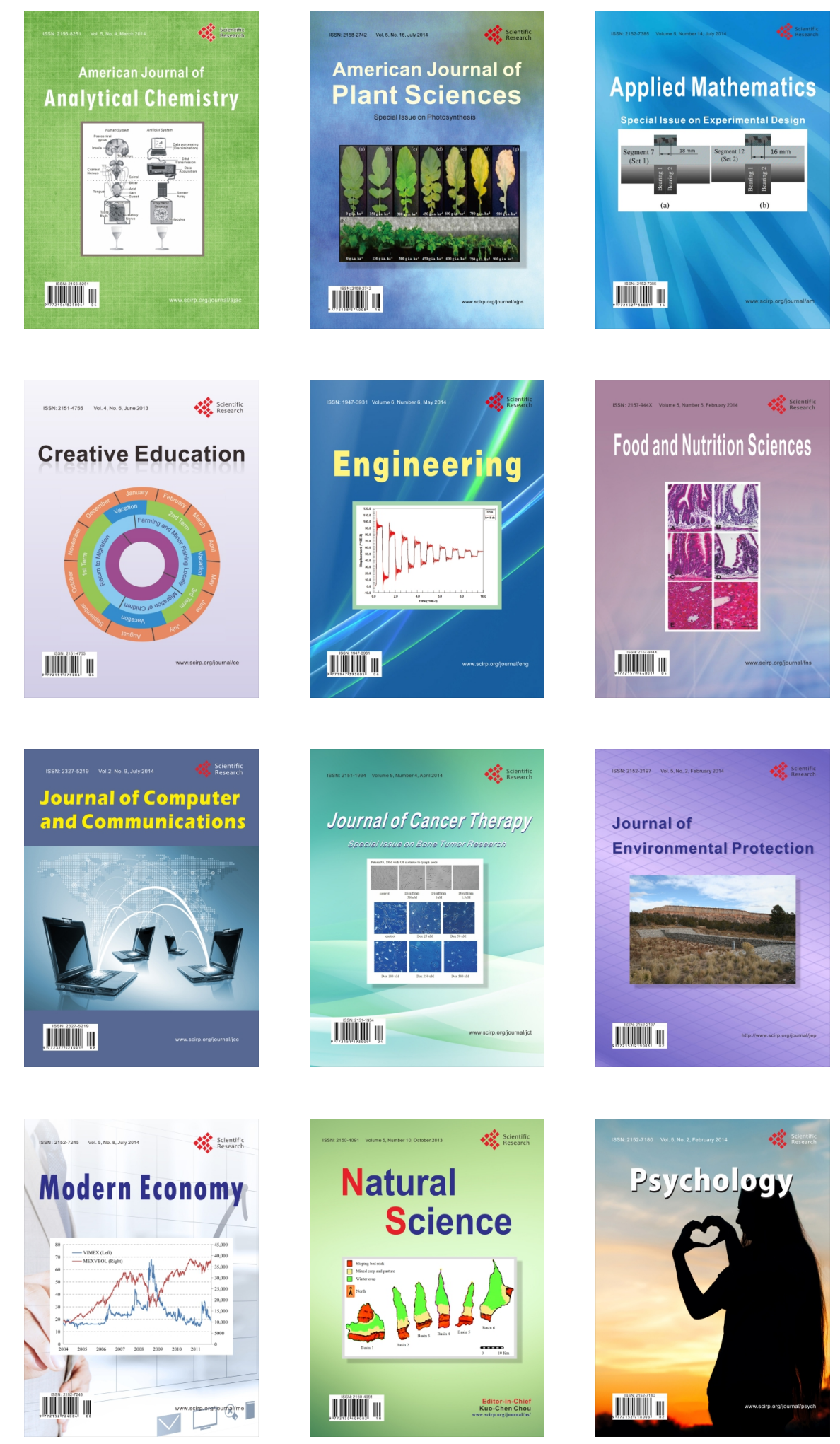